\title{
Apoptotic cell death in hemocytes of Crassostrea gigas, induced by RGD- or RGE-containing peptides
}

\author{
KaZUTAKA TERAHARA, KeISUKe G. TAKAHASHI, AND KaTSUyOSHI MORI \\ Graduate School of Agricultural Science, Tohoku University, Sendai 981-8555, Japan (tera@bios.tohoku.ac.jp)
}

\section{KEY WORDS: apoptosis, integrin, RGD, RGE, Pacific oyster, Crassostrea gigas}

\section{INTRODUCTION}

We have previously found that the spreading ability of Crassostrea gigas hemocytes was enhanced in the presence of human fibronectin (FN) (Terahara et al., to be submitted). To investigate whether the Arg-Gly-Asp (RGD) motif, an integrin-binding site in $\mathrm{FN}^{1)}$, was involved in the hemocyte spreading, we attempted to block the spreading by FN with the addition of free RGD peptides. The spreading ability decreased when the hemocytes were co-incubated with the RGD peptides. Although, the percentage hemocyte survival rapidly, and markedly decreased. Similar results were detected by the RGE peptides as control peptides.

Many types of anchorage-dependent cells require integrin-mediated adhesion to the extracellular matrix (ECM) to survive ${ }^{2)}$. By blocking adhesion to the ECM by the RGD peptides, apoptosis is induced in epithelial cells ${ }^{3)}$, endothelial cells $^{4)}$ and fibroblasts ${ }^{5)}$. Furthermore, the RGD peptides induce apoptosis of T-cells integrin-independently by direct caspase-3 activation $^{6)}$. To show that apoptosis of the C. gigas hemocytes might also be induced by the RGD or the RGE peptides, we confirmed the existence of apoptosis by Hoechst staining and DNA extraction of the hemocytes in this study.

\section{MATERIALS AND METHODS}

\section{Animals}

Hanging-cultured two-year-old Pacific oysters, $C$. gigas were obtained in Matsushima Bay, Miyagi Prefecture, Japan in March 1999.

\section{Preparation of the hemocytes}

Hemolymph was withdrawn from the adductor muscle of $C$. gigas using a plastic syringe. Hemolymph was diluted threefold with cold oyster BSS ( $\mathrm{NaCl} 26.1 \mathrm{~g}, \mathrm{KCl} 1.08 \mathrm{~g}, \mathrm{MgSO}_{4} 3.51 \mathrm{~g}, \mathrm{MgCl}_{2}$ $2.16 \mathrm{~g}, \mathrm{CaCl}_{2} 0.95 \mathrm{~g}, \mathrm{NaHCO}_{3} 0.25 \mathrm{~g}, \mathrm{NaH}_{2} \mathrm{PO}_{4}$ $0.012 \mathrm{~g}$, and glucose $1.0 \mathrm{~g} / \mathrm{pH} 7.3$ ) or with an equal volume of cold oyster BSS and anti-coagulant ${ }^{7}$. The diluent was centrifuged at $500 \times \mathrm{g}$ for $15 \mathrm{~min}$ at
$4 \mathrm{C}$. The resulting pellet was washed with $1 \mathrm{ml}$ of cold oyster BSS and centrifuged at $500 \mathrm{x} g$ for $10 \mathrm{~min}$ at $4 \mathrm{C}$. The hemocyte pellet was suspended with cold oyster BSS and placed on ice.

\section{Changes in the hemocytes viability by peptides}

Human FN (Asahi Technoglass) solution $(6.25 \mu \mathrm{g} / 50$ $\mu \mathrm{l}$ in Dulbecco's PBS) was coated on glass slides for overnight at $4 \mathrm{C}$. The prepared hemocyte suspension $\left(2 \times 10^{4}\right.$ cells $\left./ 50 \mu \mathrm{l}\right)$ was co-incubated with FN peptides (GRGDPS; Asahi Technoglass), control peptides (GRGESP; Asahi Technoglass), or other control peptides (GRADSP; Chalbiochem) at final concentrations of $0,2,3,4$, and $5 \mathrm{mM}$. These suspensions were dropped onto the human FN-coated glass surfaces and incubated for $1 \mathrm{~h}$ at $20 \mathrm{C}$. After incubation, the glass surfaces were washed with oyster BSS, and $0.4 \%$ trypan blue solution was added to the surfaces. The preparations were immediately observed under an inverted light microscope and the dead hemocytes were counted. The measurement of hemocyte viability was conducted in duplicate. Five oysters were used in this assay. To test for differences in the mean survival rate of the hemocytes, we subjected the data to the student's $t$-test.

\section{Hoechst staining}

The hemocytes $\left(4 \times 10^{5}\right.$ cells $\left./ 100 \quad \mu l\right)$ were co-incubated with or without $4 \mathrm{mM}$ of GRGDSP, GRGESP, or GRADSP in microtubes at $4 \mathrm{C}$. After 1- or 24-h incubation, the hemocytes were fixed with $4 \%$ formaldehyde solution and stained with Hoechst 33258 (Wako). The stained hemocytes were observed using fluorescence microscopy.

\section{Assay for DNA fragmentation}

The hemocytes were prepared and co-incubated by a method similar to that in the section on Hoechst staining. After 1-, 12-, or 24-h incubation, DNA was extracted from each group of treated hemocytes by the Apoptosis Ladder Detection Kit (Wako). The extracted DNA was electrophoresed on a $2 \%$ TAE-agarose gel and stained with SYBR Green I (Molecular Probe). 


\section{RESULTS}

\section{Changes in the hemocytes viability by peptides}

The RGD or the RGE peptides induced hemocyte destruction in a dose-dependent manner, however the RAD peptides did not (Fig. 1). When the hemocytes were treated with the RGD or the RGE peptides at $4 \mathrm{mM}$, the survival rates were significantly decreased to $37 \%$ or $80 \%$ compared with that of the no-additive group (94\%). At $5 \mathrm{mM}$ the percentage survival levels fell further.

\section{Hoechst staining}

Most of the hemocytes co-incubated with the RGD or the RGE peptides for $24 \mathrm{~h}$ showed the typical characteristics of apoptosis: (1) cell shrinkage and change in morula-like morph, and (2) chromatin condensation (Fig. 2).

\section{Assay for DNA fragmentation}

In both the RGD and RGE peptide-treated group, the DNA extracted from the hemocytes was detected as a ladder of DNA fragments with approximately $180 \mathrm{bp}$ increments after $12-\mathrm{h}$ incubation (Fig. 3 ). On the

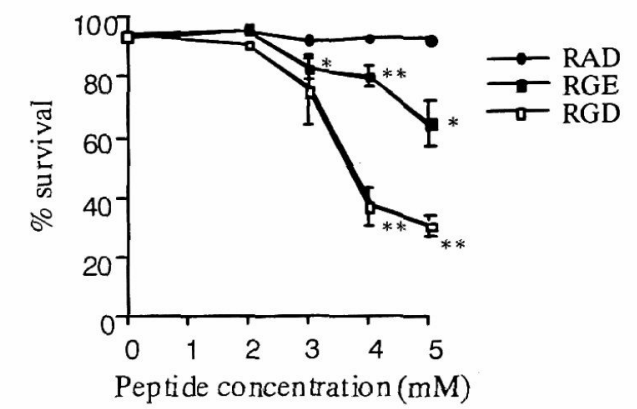

Fig. 1 Changes in viability of the $C$ gigas hemocytes treated by the peptides (GRGDSP [ $]$ ], GRGESP [-], or GRADSP $[\bullet])$. Each value shows the mean $\pm S$. E. of five animals. Asterisks (*; ${ }^{*}<0.05$ and $\left.{ }^{* *} ; p<0.01\right)$ in dicate significant $\mathrm{d}$ if ferences from the control $(0 \mathrm{mM})$.

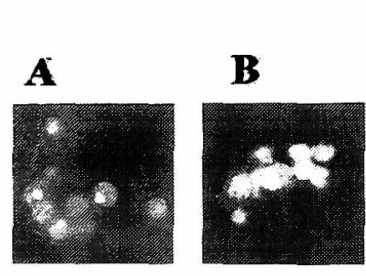

Fig. 2 light micrographs of the $C$ gigas be mocytes stained with Hoecht 33258 A; 24-h incubation without peptides $B$; 24-h incubation with GRGDSP (4mM).

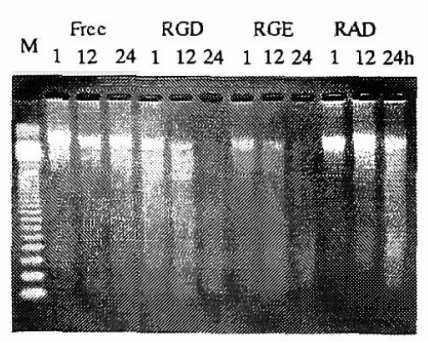

Fig. 3 Electrophoretic analysis of DNA from C. gigas hemacytes The hemocytes were treated with no peptides (Free), GRADSP(RAD) for 1,12 , or 24 h at $20^{\circ} \mathrm{C}$. $M$ is a 123 bp ladder marker. GRGDSP(RGD), GRGESP (RGE), or other hand, the RAD peptide and no-peptide groups affected DNA fragmentation only slightly.

\section{DISCUSSION}

Results obtained from Hoechst staining and DNA fragmentation analysis demonstrated that the RGD and the RGE peptides strongly induce apoptosis in the C. gigas hemocytes. Also, to our knowledge, this is the first report showing that the RGE peptides can activate the apoptotic cell death program. The mechanism of apoptosis induction in the $C$. gigas hemocytes is, however, unclear. Presently, it is considered that a specific recognition for the alignment of the peptides may be involved in the apoptosis mechanism as the RAD peptides did not induce apoptosis ( $93 \%$ hemocyte survival at $5 \mathrm{mM}$ ). It is further considered that the recognition is not too specific as the induction effect of the RGE control peptides is lower than that of the RGD in peptides.

\section{REFERENCES}

1. Ruoslahti E, Pierschbacher MD. New perspectives in cell adhesion: RGD and integrins. Science 1987; 2: 491-497

2. Meredith JE, Fazeli B, Schwartz MA. The extracellular matrix as a cell survival factor. Mol. Biol. Cell 1993; 4: 953-961

3. Aoshiba KA, Rennard SI, Spurzem JR. Cell-matrix and cell-cell interaction modulate apoptosis of bronchial epithelial cells. Am. J. Physiol. 1997; 272: L28-L37

4. Brooks PC, Montgomery MP, Rosenfeld M, Reisfeld RA, $\mathrm{Hu} \mathrm{T}$, Klier G, Cheresh DA. Integrin VB3 antagonists promote tumor regression by inducing apoptosis of angiogenic blood vessels. Cell 1994; 79: 1157-1164

5. McGill GA, Shimamura A, Bates RC, Savage RE, Fisher DE. Loss of matrix adhesion triggers rapid transformation-selective apoptosis in fibroblasts. J. Cell Biol. 1997; 138: 901-911

6. Buckley CD, Pilling D, Henriquez NV, Parsonage G, Threlfall K, Scheel-Toellner D, Simmons DL, Akbar AN, Lord JM, Salmon M. RGD peptides induce apoptosis by direct caspase-3 activation. Nature 1999; 397: 534-539

7. Söderhäll K, Smith VJ. Separation of the hemocyte populations of Carcinus maenas and other marine decapods and phenoloxidase distribution. Dev. Comp. Immunol. 1983; 7: 229-239 